\title{
Persistent habitat use by Chinook salmon Oncorhynchus tshawytscha in the coastal ocean
}

\author{
Jefferson T. Hinke ${ }^{1,2, *}$, David G. Foley ${ }^{1,2}$, Cara Wilson ${ }^{2}$, George M. Watters ${ }^{2}$ \\ ${ }^{1}$ Joint Institute for Marine and Atmospheric Research, University of Hawaii, 1000 Pope Road, Honolulu, Hawaii 96822, USA \\ ${ }^{2}$ NOAA/NMFS/SWFSC Environmental Research Division, 1352 Lighthouse Avenue, Pacific Grove, California 93950, USA
}

\begin{abstract}
We used temperature and depth data from 25 archival tags carried by Chinook salmon Oncorhynchus tshawytscha at sea to explore whether and how these fish alter their patterns of habitat use in response to variable oceanographic conditions off the coasts of Oregon and California. The Chinook salmon persistently used a narrow range of thermal habitats $\left(8\right.$ to $\left.12^{\circ} \mathrm{C}\right)$ during all months of the year, irrespective of location, time or year of release. In general, individuals appeared to adjust their vertical position in the water column to maintain this persistent thermal experience. There was noticeable individual and seasonal variation in the depths used, with the deepest habitats being used during winter. The patterns of depth use were related to the annual cycles of surface temperatures and surface productivity. Chinook salmon synchronously responded to anonymously warm surface temperatures in August 2003 by using relatively deeper habitats. Declines in surface productivity during autumn were accompanied by an apparent switch from relatively shallow habitats, to deeper, presumably benthic, habitats. The persistent use of a narrow range of temperatures suggests that variation in oceanographic conditions do not necessarily correspond to variation in the temperatures that Chinook salmon use. The effects of environmental variability on their growth and maturation in the California Current may, therefore, be relatively independent of temperature-mediated physiological responses. Rather, it seems relatively more important to understand how variable ocean conditions affect the food-web topology in the thermal habitats that Chinook salmon use.
\end{abstract}

KEY WORDS: Pacific salmon · Essential fish habitat · Archival tags $\cdot$ California Current $\cdot$ Sea-surface temperature $\cdot$ Surface chlorophyll

\section{INTRODUCTION}

Changes in marine environmental conditions have been correlated with variation in the survival rates and production of many marine fishes (e.g. Beamish 1993, Clark et al. 1999, Rodriguez-Sánchez et al. 2002), including Pacific salmon Oncorhynchus spp. Indices of salmon production, including commercial fishery catches and the numbers of spawning adults, expressed both in absolute abundance (escapement) and as a fraction of parent stock abundance (recruitment), have been correlated to long-term variation in general ocean conditions on basin-wide scales (e.g. Beamish \& Bouillon 1993, Adkison et al. 1996), and annual variation in the number of spawning adults, adult body size and survival rates from eggs to adult spawners are correlated with changes in regionalscale environmental conditions (e.g. Peterman et al. 1998, Hobday \& Boehlert 2001, Mueter et al. 2002). Despite the numerous correlations of environmental indices to variation in salmon populations at multiple spatial and temporal scales, questions remain concerning the mechanisms that link environmental variation and salmon populations (e.g. Gargett et al. 2001) and how salmon respond to changing ocean conditions (Botsford \& Lawrence 2002).

The period of ocean residency for Pacific salmon can range from 6 mo to over 6 yr (Pearcy 1992). During this time, the majority of somatic and gonadal growth occurs, and the energy reserves essential for successful 
migrations from ocean habitats to natal freshwater spawning sites are accumulated. Contemporary changes in marine conditions that affect primary productivity, food supply, or the availability and extent of suitable habitats may, therefore, affect both growth and maturation rates of salmon (Hinch et al. 1995, Roy et al. 2004, Snover et al. 2005), and their spatial distributions in the coastal ocean (Brodeur et al. 2003).

The coastal California Current is used by maturing salmon and exhibits short- and long-term cycles in temperature, salinity, upwelling and nutrient supply (Hickey 1998, Mendelssohn et al. 2003). Such variation affects the entire California Current food web, changing primary productivity at the base of the food web (Collins et al. 2003, Lynn et al. 2003) and affecting the abundance, distribution and species composition of animals at higher trophic levels (Pearcy \& Schoener 1987, Brodeur et al. 2003). It is, however, not clear whether changes in ocean conditions cause the patterns of habitat use by salmon to change. To understand how variation in ocean conditions affects salmon populations, it seems necessary to describe their patterns of habitat use in the ocean, preferably encompassing the variability at seasonal and interannual scales.
Characterizing the habitats that are used by marine animals has been facilitated by the recent application of data-storage tags (e.g. Bradshaw et al. 2002, Itoh et al. 2003, Sims et al. 2003). Such tags have been used widely on Pacific salmonids to characterize migratory patterns in the open ocean (e.g. Ogura \& Ishida 1995, Friedland et al. 2001) and short-term patterns of habitat use in the coastal ocean (Hinke et al. 2005). An ongoing effort to tag Chinook salmon Oncorhynchus tshawytscha off the Oregon and California coasts has yielded numerous tag returns across $5 \mathrm{yr}$, each with time series of the temperatures and depths used during the time that each fish was at liberty. These data afford the opportunity to examine whether and how Chinook salmon alter their patterns of habitat use in response to variation in ocean conditions over a range of time scales.

We examined relationships between habitat use by Chinook salmon in the California Current (from central California to northern Oregon), and variations in seasurface temperatures, subsurface temperatures and surface chlorophyll a concentrations. Our focus was to examine the patterns of temperature and depth use by individuals representing different stocks, from different years and different months of the year. This work

Table 1. Oncorhynchus tshawytscha. Summary of data on release, recovery and ocean residence. na: not applicable

\begin{tabular}{|c|c|c|c|c|c|c|c|c|}
\hline \multirow{2}{*}{$\begin{array}{l}\text { Chinook } \\
\text { tag no. }\end{array}$} & \multirow{2}{*}{$\begin{array}{c}\text { Release } \\
\text { date }(\mathrm{mo} / \mathrm{d} / \mathrm{yr})\end{array}$} & \multirow{2}{*}{$\begin{array}{c}\text { Recovery } \\
\text { date }(\mathrm{mo} / \mathrm{d} / \mathrm{yr})\end{array}$} & \multirow{2}{*}{$\begin{array}{l}\text { Recovery } \\
\text { location }\end{array}$} & \multicolumn{2}{|c|}{ Buoy nearest } & \multirow{2}{*}{$\begin{array}{c}\text { Days in } \\
\text { ocean }\end{array}$} & \multirow{2}{*}{$\begin{array}{c}\text { Mean } \\
t\left({ }^{\circ} \mathrm{C}\right)\end{array}$} & \multirow{2}{*}{$\begin{array}{c}\text { Mean } \\
\text { depth }(\mathrm{m})\end{array}$} \\
\hline & & & & release & recovery & & & \\
\hline 287 & 08/31/00 & 09/16/00 & River & Eel River & na & 12 & 11.2 & 30.7 \\
\hline 290 & $08 / 22 / 00$ & $01 / 03 / 01$ & River & Eel River & na & 12 & 11.4 & 11.1 \\
\hline 291 & $08 / 19 / 00$ & $10 / 02 / 00$ & Ocean & Eel River & St. Georges ${ }^{a}$ & 45 & 10 & 53.4 \\
\hline 303 & $08 / 17 / 00$ & $09 / 05 / 00$ & Ocean & Eel River & St. Georges & 19 & 10.3 & 36.1 \\
\hline 304 & $08 / 16 / 00$ & $10 / 13 / 00$ & River & Eel River & na & 12 & 12.2 & 7.6 \\
\hline 470 & $04 / 05 / 01$ & 05/11/01 & Ocean & MBARI M1 & MBARI M1 & 37 & 10.5 & 31.7 \\
\hline 471 & $04 / 12 / 01$ & 05/08/01 & Ocean & MBARI M1 & MBARI M1 & 27 & 10.7 & 18.8 \\
\hline 606 & $09 / 05 / 03$ & $10 / 16 / 03$ & River & Eel River & na & 22 & 10.8 & 46.4 \\
\hline 615 & $09 / 05 / 03$ & $10 / 15 / 03$ & River & Eel River & na & 23 & 10.6 & 48.6 \\
\hline 628 & 09/04/03 & $10 / 21 / 03$ & River & Eel River & na & 13 & 10.8 & 47.4 \\
\hline 712 & $07 / 08 / 03$ & $10 / 03 / 03$ & River & Point Arena & na & 56 & 10.8 & 35.7 \\
\hline 717 & $07 / 09 / 03$ & 08/09/03 & Ocean & Point Arena & Point Arena & 32 & 10.2 & 24.1 \\
\hline 1051 & $07 / 25 / 03$ & $11 / 03 / 03$ & River & Bodega Bay & na & 58 & 10 & 43.2 \\
\hline 1059 & $07 / 09 / 03$ & $10 / 06 / 03$ & River & Point Arena & na & 77 & 9.8 & 48 \\
\hline 1067 & $07 / 25 / 03$ & $11 / 29 / 03$ & River & Bodega Bay & na & 63 & 10.9 & 45.1 \\
\hline 1074 & $08 / 05 / 03$ & $11 / 03 / 03$ & River & Point Arena & na & 33 & 9.7 & 53.4 \\
\hline 1200 & $02 / 28 / 02$ & $05 / 19 / 03$ & Ocean & Bodega Bay & Stonewall Banks & 446 & 9.3 & 39.4 \\
\hline 1226 & $09 / 05 / 02$ & $03 / 07 / 03$ & Ocean & Eel River & Point Arena & 184 & 8.6 & 175.7 \\
\hline 1229 & $09 / 12 / 02$ & $05 / 02 / 03$ & Ocean & Eel River & Point Arena & 234 & 9.3 & 116.9 \\
\hline 1238 & $07 / 24 / 02$ & $09 / 20 / 02$ & Ocean & Eel River & St. Georges & 57 & 9.7 & 23.4 \\
\hline 1242 & $09 / 11 / 02$ & $05 / 28 / 03$ & River & Eel River & na & 240 & 9.5 & na \\
\hline 1254 & $09 / 10 / 02$ & $10 / 30 / 02$ & River & Eel River & na & $\begin{array}{r}240 \\
19\end{array}$ & 11 & 26.8 \\
\hline 1793 & $08 / 05 / 03$ & $09 / 28 / 03$ & Ocean & Point Arena & Stonewall Banks & 55 & 8.5 & 84.2 \\
\hline 1941 & $08 / 21 / 03$ & $10 / 20 / 03$ & River & Point Arena & na & 39 & 10 & 56.8 \\
\hline 1994 & $07 / 09 / 03$ & $11 / 03 / 03$ & River & Point Arena & na & 79 & 9.6 & 50.3 \\
\hline
\end{tabular}

${ }^{a}$ This recovery position was closer to National Data Buoy Center Stn 46015, but as sea-surface temperature data were not available for this station in 2000, we used St. Georges buoy as the buoy nearest recovery for Tag 291 
expands an earlier analysis (Hinke et al. 2005) of individual variation in the patterns of habitat use by Chinook salmon during autumn months. Hinke et al. (2005) reported the use of a narrow range of temperatures $\left(9\right.$ to $\left.12^{\circ} \mathrm{C}\right)$ and a high degree of individual variation in the patterns of daily depth use by Chinook salmon. Here, we provide a more synoptic view of habitat use. We (1) describe the persistent use of a narrow range of temperatures by Chinook salmon throughout the year, (2) link individual and seasonal variation in depth use to ocean conditions as measured by sea-surface temperature (SST) and surface chlorophyll a concentrations at multiple locations along the California and Oregon coasts, and (3) identify a shared behavior in response to changes in the availability of suitable ocean habitat.

\section{MATERIALS AND METHODS}

Archival tag data. We used temperature and pressure (depth) data recorded by data-storage tags to describe the habitats used by Chinook salmon in the coastal California Current. Walker et al. (2000) and Hinke et al. (2005) described the data-storage tags that we used and the method of tag attachment. Specifications for the LTD 1100 tags we used are available online from the manufacturer, Lotek Wireless, at www.lotek.com (use of brand name does not imply endorsement by the National Marine Fisheries Service). Briefly, fish were caught with sport or commercial trolling gear, the tags were attached to the salmon ventral to the dorsal fin, and each fish was held in a flow-through seawater tank to allow recovery from the tagging procedure prior to release. The tags were marked with contact and reward information to improve reporting of recaptured fish and the recovery of data-storage tags.

At the time of writing, 46 tags have been recovered from 340 releases over a 5 yr period (2000 to 2004). For our primary analyses, we used the data from 25 tags that had been recovered by January 2004 (Table 1). These data contain observations of temperature and depth use by Chinook salmon during every month of the year, and there are at least 2 time series of depth use and at least 4 time series of temperature use during every month except June (Table 2). The bulk of the data were collected between July and October. Releases occurred in coastal waters between Monterey Bay $\left(36.7^{\circ} \mathrm{N}\right)$ and Eureka, California $\left(41.1^{\circ} \mathrm{N}\right)$. Recoveries ranged from Monterey Bay $\left(36.7^{\circ} \mathrm{N}\right)$ to near the Columbia River mouth $\left(45.6^{\circ} \mathrm{N}\right)$, and inland on the Sacramento and Klamath/Trinity river systems (Fig. 1). Temperature and depth data collected after the fish entered freshwater were excluded from these analy-
Table 2. Oncorhynchus tshawytscha. Monthly data coverage from 25 tags over 4 yr. No. of depth records differs from no. of temperature records because pressure sensors malfunctioned in 4 tags

\begin{tabular}{|llcc|}
\hline Month & $\begin{array}{l}\text { Years } \\
\text { represented }\end{array}$ & $\begin{array}{c}\text { Temperature } \\
\text { records (n) }\end{array}$ & $\begin{array}{c}\text { Depth } \\
\text { records (n) }\end{array}$ \\
\hline January & 2003 & 4 & 2 \\
February & 2003 & 4 & 3 \\
March & 2002,2003 & 4 & 3 \\
April & 2001,2002 & 5 & 4 \\
May & 2001,2002 & 5 & 4 \\
June & 2002 & 1 & 1 \\
July & 2002,2003 & 8 & 8 \\
August & $2000,2002,2003$ & 16 & 16 \\
September & $2000,2002,2003$ & 22 & 20 \\
October & $2000,2002,2003$ & 7 & 6 \\
November & 2002 & 4 & 3 \\
December & 2002 & 4 & 3 \\
& & & \\
\hline
\end{tabular}

ses. River entry was identified by abrupt and sustained changes in the temperatures and depths recorded by the tag. Specifically, the time of river entry is marked

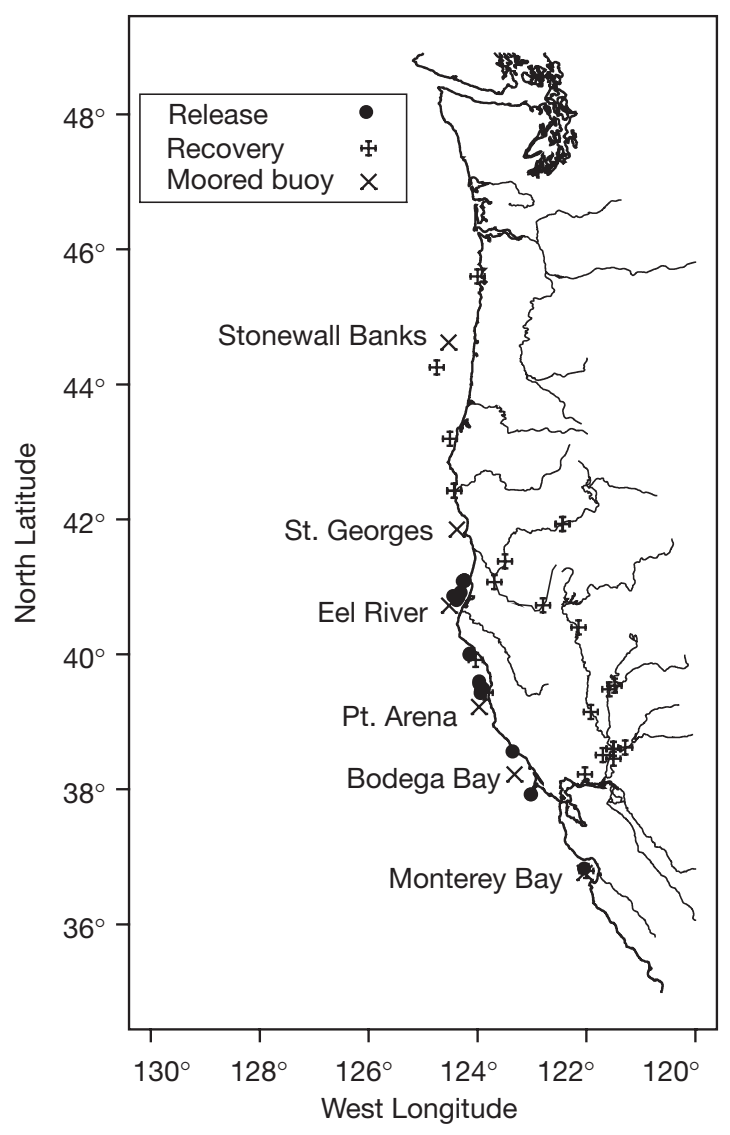

Fig. 1. Release and recovery locations of Chinook salmon and moored NOAA and Monterey Bay Aquarium Research Institute buoy locations 
by consistently warmer temperatures and shallow depths.

The sampling intervals in each time series ranged from 1.875 to $60 \mathrm{~min}$ and provided continuous observations of temperature and depth use from the time of release until recapture. Sampling intervals on the tag were determined by the length of time the tag was at liberty. Initial measurements were taken approximately every 15 s. Once the memory was full (16384 observations), the sample interval doubled and every other previous observation was overwritten. This procedure continued until the memory was filled at the doubled interval; then the interval doubled again and the process was repeated (full details of this sampling algorithm are provided at www.lotek.com). An analysis of this subsampling protocol suggested that the mean temperatures and depths recorded by the tags were not biased by the final sample interval (data not shown).

To standardize the data, we calculated mean temperatures and depths over both 24 and 2.4 h (10 observations $\mathrm{d}^{-1}$ ) intervals. The longer interval was used for comparison with environmental data sampled at low frequency (weekly or daily). The shorter interval was chosen to preserve variation that might arise from short-term, individual behaviors and for comparison with environmental data sampled at high frequency. We also pooled all temperature and depth data by month to calculate mean and median monthly temperatures and depths used by Chinook salmon. The original time series of temperature and depth recorded by each tag are available from the Environmental Research Division, formerly known as the Pacific Fisheries Environmental Laboratory, at www.pfeg.noaa.gov.

Moored NDBC and MBARI buoys: surface and subsurface temperatures. We compared the temperatures experienced by Chinook salmon to sea-surface temperatures (SSTs) and subsurface temperatures measured by buoys moored along the coast. Sea-surface temperature data were based on hourly observations from moored National Data Buoy Center (NDBC) and Monterey Bay Aquarium Research Institute (MBARI) buoys that encompassed the latitudinal extent of ocean releases and recoveries (Fig. 1) and that were operational during the time period of tag deployments. We used NDBC Moorings 46013 (Bodega Bay), 46014 (Point Arena), and 46022 (Eel River) and the MBARI M1 buoy to represent condition near release locations (Fig. 1). We used the moorings at St. Georges (NDBC Buoy 46027) and Stonewall Banks (NDBC Buoy 46050) to represent the conditions at the northern extent of tag recoveries (Fig. 1). The MBARI M1 mooring represented our southernmost buoy. We converted the hourly buoy observations to $2.4 \mathrm{~h}$ means and paired the temperature series recorded by each archival tag with matching series of SST data from at least 3 differ- ent buoys that represented the release and recovery locations, as well as the northern and southern-most buoys within the range of tag recoveries. We also pooled all SST data from these buoys to calculate a mean, coastal SST for each month of the year for comparison with monthly depth use by Chinook salmon.

The MBARI M1 mooring measured subsurface temperatures every hour at depths of $1,10,20,40,80,100$, 150,200 and $250 \mathrm{~m}$. We used the subsurface temperature data in 2 ways. First, we compared the temperatures recorded by the tags with the temperatures at $150 \mathrm{~m}$ because the median of the maximum depths used by all the tagged salmon was $177 \mathrm{~m}$. Second, we interpolated subsurface temperatures between the depths sampled by the M1 buoy to create a continuous temperature-at-depth profile of Monterey Bay from 2000 to 2003. We then mapped the depth trajectories of each individual salmon onto the subsurface temperature profile of Monterey Bay to examine whether its patterns of depth use were similar to the vertical temperature distributions in Monterey Bay. It is important to note that the comparisons of the depths and temperatures used by Chinook salmon to the thermal conditions along the coast, particularly for the comparisons of subsurface temperatures in Monterey Bay, are not presented to suggest that the fish actually used all these habitats. Rather, we explore whether the variations in ocean temperatures at the surface and at depth may relate to the patterns of habitat use by Chinook salmon in the California Current.

Satellite data: SST and chlorophyll a. Maps of monthly mean SSTs were compiled from individual 'advanced very high resolution radiometer' (AVHRR) satellite images provided by the NOAA West Coast CoastWatch node. The base SST maps were then transformed using a single probability density function for the distribution of temperatures used by all 25 Chinook salmon. The resulting SST-based maps identified the ocean areas where SSTs corresponded to the full temperature range used by Chinook salmon. We named this SST-based assessment of the availability of surface areas with temperatures that matched the distribution of temperatures used by Chinook salmon an 'index of habitat potential' (IHP). For presentation, we focus specifically on the summer months (May to September) from 2000 through 2003 when commercial salmon fisheries operated in California. For each monthly composite image, we computed the total surface area of the coastal ocean where the IHP was $>0.25$. The arbitrary IHP cut-off value of 0.25 corresponds to SSTs between 7.5 and $12.5^{\circ} \mathrm{C}$ and was chosen to match the primary range of temperatures used by Chinook salmon. We then compared monthly median depth use by all salmon to the area of potential surface habitat with an IHP $>0.25$. Finally, we made a 
post-hoc test of the relationship between potential habitat area and depth use by Chinook salmon with depth data from an additional 8 individuals that were released and recaptured in the summer of 2004. The data from these tags are not presented elsewhere in this manuscript.

Finally, patterns of depth use by Chinook were compared to surface productivity using chlorophyll a concentrations derived from the 'sea-viewing wide fieldof-view sensor' (SeaWiFS) ocean-color data. Daily sea-surface chlorophyll a concentrations (SCCs) were interpolated from $8 \mathrm{~d}$ averaged SeaWiFS images over a $0.2^{\circ}$ latitude by $0.2^{\circ}$ longitude area centered on each buoy location. The SCCs were analyzed in the small areas surrounding the buoys to compare local variations in chlorophyll a near the known release and recovery locations along the coast. We also calculated coast-wide daily and monthly mean SCCs from the interpolated values around each buoy to compare the mean SCCs to the mean daily and monthly depths used by Chinook salmon.

Data analysis. Given the high degree of spatial variability in oceanographic conditions within the California Current (Hickey 1998, Mendelssohn et al. 2003), it is likely that the environment experienced by any individual Chinook salmon will differ from the environment experienced by others at a given point in time.
Over longer time periods, however, average environmental experiences may converge because of physiological requirements, or because of regional similarities in oceanographic conditions (i.e. Mueter et al. 2002). Therefore, to compare the time series of temperatures and depths recorded by the tags, and to compare the temperatures experienced by the salmon with to the buoy temperature data and satellite SCC data, we converted each standardized temperature and depth time series into series of cumulative sums.

The cumulative sum will approximate a line with constant slope provided there are no trends or cycles in the data, which cause the cumulative sum to grow exponentially or oscillate, respectively. Comparing cumulative sums allows a simple assessment of the differences between time series that might otherwise be obscured by high-frequency variability. It has a disadvantage, however, in that only trends or cycles of relatively large magnitude within the time series will cause the slope of the accumulated time series to change appreciably. Thus, the cumulative sum offers a conservative metric for comparing time series. We assume that a divergence in the sequence of cumulative sums of 2 similarly-scaled time series can be interpreted as a large difference in the time series (see Fig. 2 for example of the transformation from a raw time series to a cumulative sum series).
Fig. 2. Oncorhynchus tshawytscha. Standardized time series of (A) temperature, (B) depth, and cumulative sums for $2.4 \mathrm{~h}$ series of $(\mathrm{C})$ temperature and (D) depth for 2 Chinook salmon (Tag nos. 1226 and 1229) that spent over 6 mo at sea. Both fish were released in 2002 and recaptured in 2003. Dates are mo/d
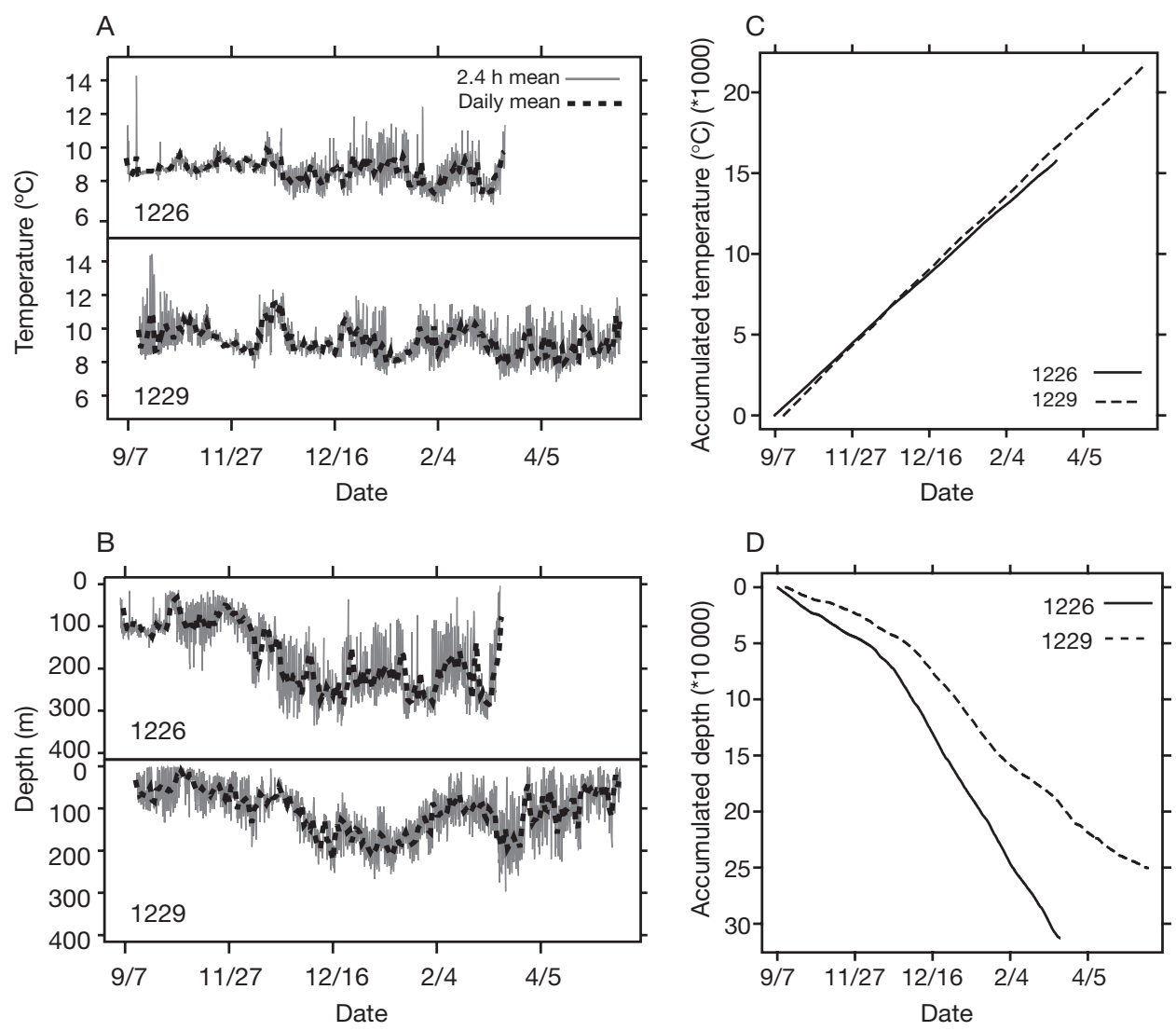
We used the cumulative sums to compare individual patterns of temperature and depth use by Chinook salmon and to compare the temperature experience of each individual to SSTs along the coast and subsurface temperatures in Monterey Bay. In general, subsurface temperatures are cooler than surface temperatures, and because Chinook salmon are known to use subsurface habitats extensively (Ogura \& Ishida 1995, Orsi \& Wertheimer 1995, Hinke et al. 2005), we expected SSTs to accumulate faster than the temperatures actually experienced by the fish. Nevertheless, for periods when SST conditions were similar to the temperatures experienced by the fish, we also expected these 2 series to accumulate at roughly equal rates. A potential problem with this method is that movement away from the area near a given buoy could account for a divergence of temperature records. If so, we expect that fish temperature records would tend to converge with the buoy toward which it was moving. Our comparisons of each fish with multiple buoys attempts to account for horizontal movements.

We also examined the variation in temperature and depth data recorded by the tags with a variance components model, implemented in S-Plus 6.2 (Insightful Corporation 2001). We treated individuals and months as random factors and estimated, via maximum likelihood, the percent of variation in temperature and depth that could be explained by each factor. We used data from 4 tags $(1200,1226,1229$ and 1242) for temperature and data from 2 tags (1226 and 1229) for depth. These tags were chosen to achieve balanced data sets that spanned the longest, continuous time period (12 September 2002 to 8 March 2003) of recorded temperature and depth use by multiple individuals.

\section{RESULTS}

Time-series plots of the standardized temperature and depth data recorded by archival tags from 2 individuals provided examples of long-term habitat use in the coastal ocean (Fig. 2A,B). Both fish were tagged near Eureka, California, in September 2002 and were recaptured near Point Arena, California the following spring. Both fish spent substantial time within a narrow range of temperatures $\left(8\right.$ to $12^{\circ} \mathrm{C}$ ) for the duration of their time at liberty. The persistent use of temperatures in this range resulted in similar rates of temperature accumulation for both tags (Fig. 2C). From release in September until early December, both fish primarily used depths within the upper $150 \mathrm{~m}$. Between December and February, they used depths that typically averaged $200 \mathrm{~m}$, and waters shallower than $100 \mathrm{~m}$ were used rarely until late February or early March of the following year (Fig. 2B). This seasonal shift in vertical orientation by both fish caused depth to accumulate faster during the winter (Fig. 2D). The increases in the rate of depth accumulation during winter were not accompanied by strong decreases in the rates of temperature accumulations (Fig. 2C,D).

The persistent temperature experiences illustrated in Fig. 2 were representative of the temperature experiences of all the fish considered here. All tags measured a similarly narrow range of temperatures through time, and this was reflected in similar rates of temperature accumulation for all 25 Chinook (Fig. 3A). Regardless of year (2000 or 2003), month of release (February to September), location of release (Fig. 1), length at release (range $=57$ to $80 \mathrm{~cm}$ fork length, mean $=69 \mathrm{~cm} \mathrm{FL}$ ), or location of recapture (Fig. 1), the rates of temperature accumulation (the slopes of each line) were similar, even for tags that recorded up to 15 mo of continuous observations (Fig. 3A). Note, however, that the temperatures used by Chinook salmon are not the same at any given point in time, and the resulting temperature accumulations of all individuals are neither linear nor parallel (Fig. 3A). Nonetheless, a variance components model indicated that there was negligible individual or monthly variation in the temperatures used by the 4 Chinook salmon that overwintered at sea (Table 3).

The accumulations of depth during summer and autumn months were relatively more variable between individuals (Fig. 3B). Accumulation rates from May to November were less steep than during winter months, reflecting a more shallow distribution from May to November. More variation in depth use was attributable to variation among individuals and months than was the case for temperature use (Table 3).

Irrespective of the date of release, all Chinook salmon generally experienced temperatures that were similar to SSTs at all buoys throughout the study area. Fig. 4 presents these comparisons for each tag that represented the longest temperature record from each year. Note that in 2001 (Fig. 4.), the longest time series occurred earlier in the year (April to May) and was much shorter than the time series for other years. During April and May, SSTs throughout the study area accumulated at rates that were similar to the rates at which Chinook salmon accumulated temperature experiences (Fig. 4, Tags 472 and 1200). As times at liberty extended into August and September for Tags 291, 1200 and 1994, the temperature accumulations at the buoys near release locations (Fig. 4I-L) and buoys near recovery locations (Fig. 4C,E,J) diverged from temperature accumulations of the fish. Within years, the timing of this divergence varied by buoy, but occurred earlier at locations where SSTs were relatively warmer (e.g. Fig. 4A,D,O). For a given buoy, the timing of divergence varied across years. 

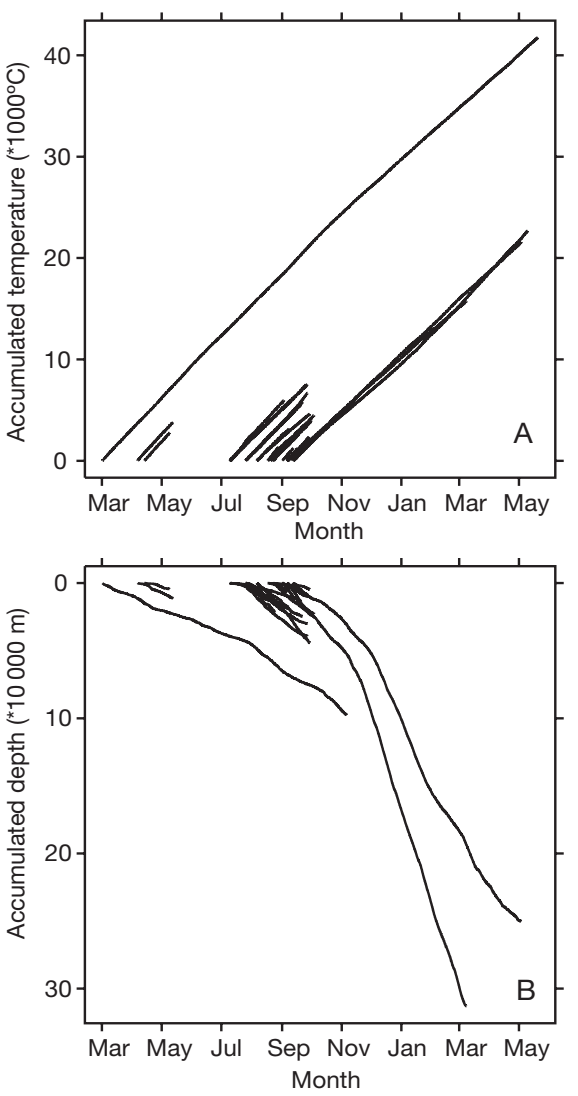

Fig. 3. Oncorhynchus tshawytscha. (A) Cumulative temperature experiences of all 25 Chinook plotted from days of release; (B) cumulative depth experiences of 24 Chinook plotted from days of release. Pressure sensors malfunctioned on 4 tags and depth records are therefore shorter than corresponding temperature records

In Monterey Bay, where we were able to compare temperatures experienced by the fish with both subsurface and surface temperatures, the temperatures that fish experienced were matched closely to the temperatures recorded at a depth of $150 \mathrm{~m}$ (Fig. 4M-P). This was consistent with our observations that Chinook salmon used deeper depths during the late autumn and winter (Fig. 2B). Surface temperatures in Monterey Bay consistently overestimated temperature accumulations for all but 1 tag (472) which was released in Monterey Bay during April 2001 and recorded the use of shallow depths by that fish.

The depths used by each fish were similar to the depth distribution of water temperatures in the 8 to $12^{\circ} \mathrm{C}$ range in the subsurface habitats recorded by the MBARI M1 buoy (Fig. 5). As surface waters in Monterey Bay warmed and the depth of 8 to $12^{\circ} \mathrm{C}$ water contours increased, there was a corresponding increase in the use of deeper habitats by Chinook salmon, irrespective of their release date or location along the coast.
The temperature accumulations of all fish released in 2003 synchronously diverged from the SSTs, irrespective of the previous amount of time at liberty and the locations of release (Fig. 6). The divergence also occurred when we compared the temperature accumulations of the fish with the SST accumulations at other buoys along the coast (Fig. 4D,H,L,P). Prior to about 8 August, the temperatures experienced by the fish were similar to SSTs in the study area. After 8 August, coastal SSTs warmed, SST accumulations became steeper, and SSTs diverged from the thermal experiences of the fish. Temperature accumulations from Chinook salmon released after 8 August diverged from SSTs at the buoys near release locations almost immediately (Fig. 6).

The availability of potential surface habitat varied both intra-annually and interannually, and was correlated with the vertical distribution of Chinook salmon. Intra-annually, the IHP indicated a general decline in habitat availability during the summer; surface habitats were widespread in May and June and became more localized as the summer progressed (Fig. 7). Although salmon continued to use surface habitats during the summer and autumn (Fig. 2, and Hinke et al. $2005)$, this reduction in available habitat did precede the use of greater depths in winter (Figs. 2 \& 3). Interannual variation in the availability of surface habitat was more clearly related to the depths used by Chinook salmon. For example, during August 2000 and 2002, the IHP indicated that habitat was meridionally widespread (Fig. 7), and the fish used waters $<40 \mathrm{~m}$ most frequently (median depths $=7.8$ and $18.7 \mathrm{~m}$ in August 2000 and 2002, respectively). In contrast, during August 2003, potential surface habitat was negligible (Fig. 7), and the fish used waters between 40 and $100 \mathrm{~m}$ most frequently (median depth $=60.3 \mathrm{~m}$ ). This inverse relationship between the spatial extent of surface habitat, as indicated by the IHP, and the depths used by Chinook salmon generally appeared to hold throughout May to September. The deepest habitats

Table 3. Oncorhynchus tshawytscha. Percent total variation in temperature and depth use due to individual and to month. Data from 7 mo (September to March) used for analysis. n: no. tags, no. of observations used in each analysis for temperature and depth, respectively; individual $\times$ month: interaction between individual and month

\begin{tabular}{|lcc|}
\hline Variance component & $\begin{array}{c}\text { Temperature } \\
(\mathrm{n}=4,7068)\end{array}$ & $\begin{array}{c}\text { Depth } \\
(\mathrm{n}=2,3534)\end{array}$ \\
\hline Individual & 3.128 & 18.083 \\
Month & 0 & 40.159 \\
Individual $\times$ Month & 36.48 & 6.285 \\
Residual & 60.393 & 35.473 \\
\hline
\end{tabular}


were used only when potential surface habitats were restricted spatially (Fig. 8). When the total surface area of the ocean with an IHP value $>0.25$ was less than $25000 \mathrm{~km}^{2}$, median depth use increased as habitat area decreased ( $d f=6, R^{2}=0.58, p=0.027$ ). This rela- tionship was further supported by data collected during the summer of 2004 (Fig. 8). Although consideration of areas less than $25000 \mathrm{~km}^{2}$ excluded 4 mo (May 2001, 2002, 2003; June 2002) in which there were extensive offshore areas with high IHP values, including
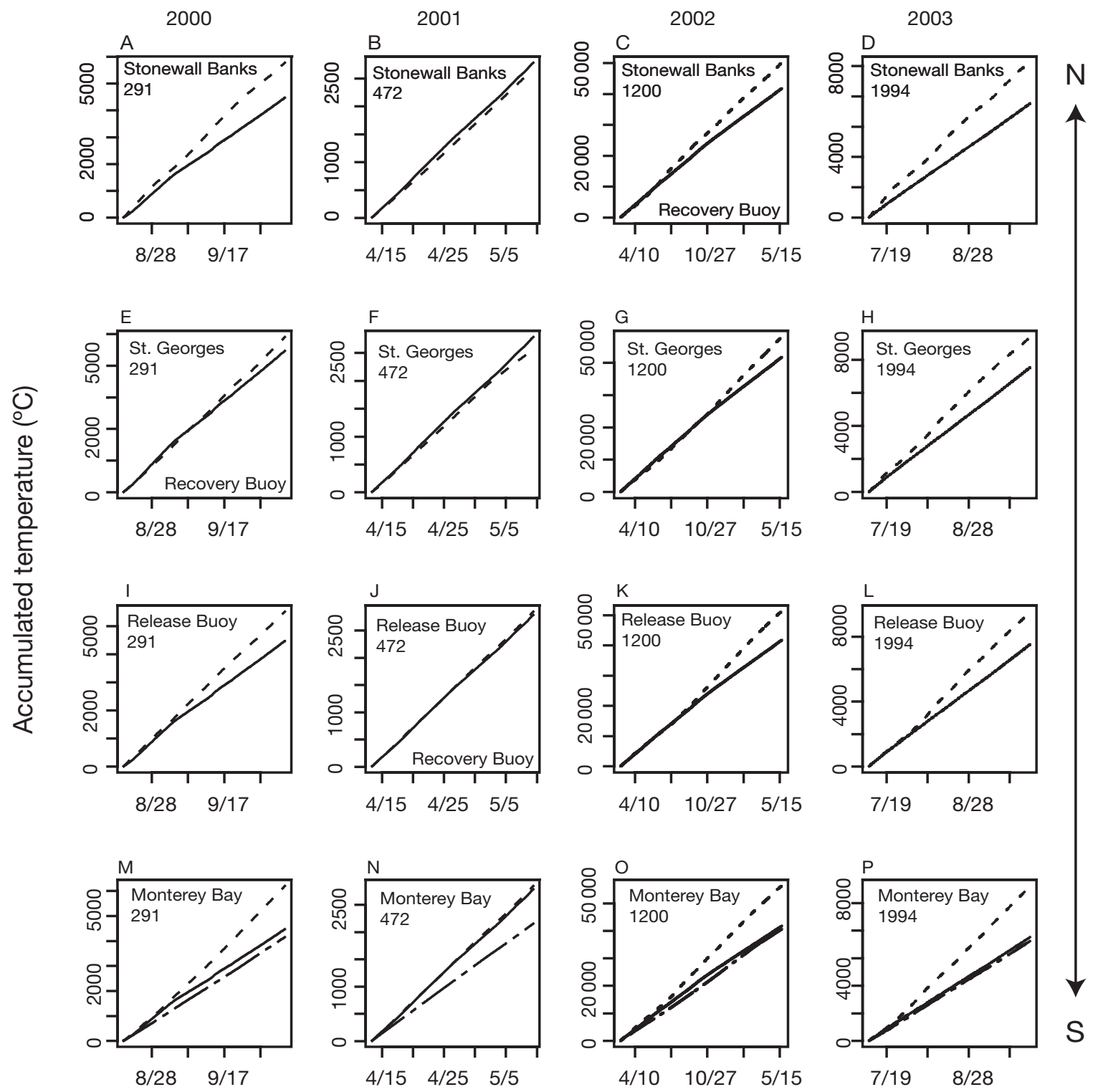

Date

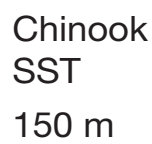

Fig. 4. Oncorhynchus tshawytscha. Temperature experience of 1 fish from each year compared with sea-surface temperatures (SST) at (A-D) Stonewall Banks, (E-H) St. Georges, (I-L) buoy nearest to each respective release position, and (M-P) to surface and subsurface $(150 \mathrm{~m})$ temperatures in Monterey Bay. 291, 472, 1200, 1994: tags representing longest time series for each year; buoy nearest to release location for each tag was Eel River, MBARI M1, Bodega Bay and Point Arena, respectively. Tags 291, 472 and 1200 were recovered from ocean near the St. Georges, MBARI MI and Stonewall Banks buoys, respectively. Note that scales of $x$ - and $y$-axes differ between years. Dates are $\mathrm{mo} / \mathrm{d}$ 


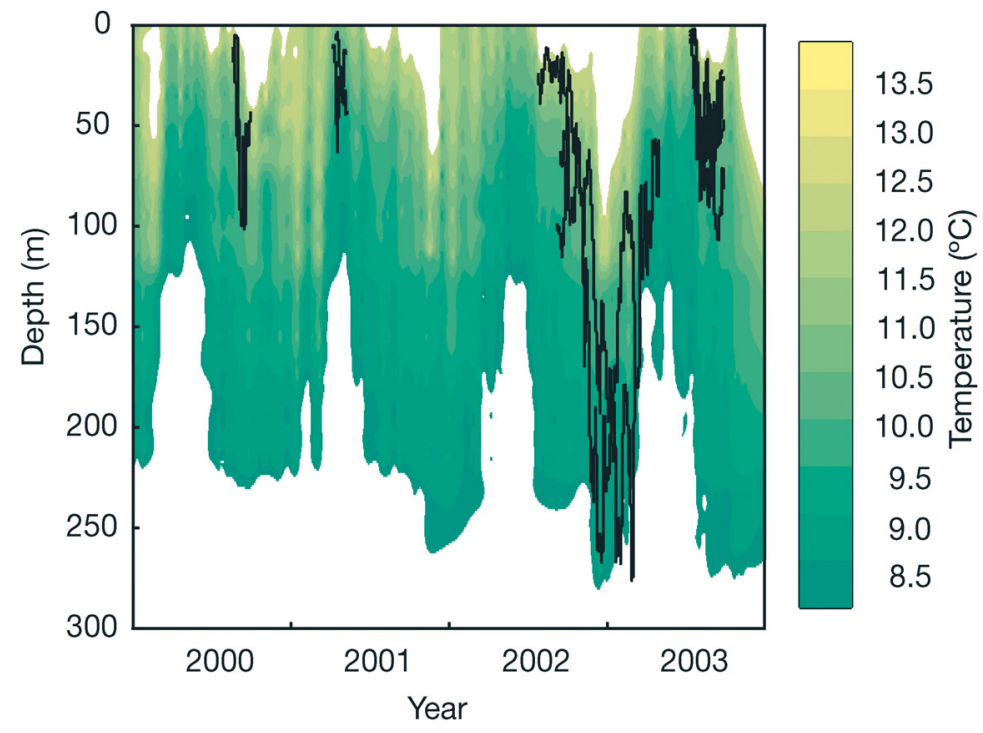

Fig. 5. Oncorhynchus tshawytscha. All depth trajectories for each year overlaid on subsurface temperature profile of Monterey Bay by temperatures between 8 and $12^{\circ} \mathrm{C}$. Hinke et al. (2005) used a subset of the data presented here and observed that, from August to October, Chinook salmon used the temperature range of 9 to $12^{\circ} \mathrm{C}$ at least $52 \%$ of the time, even when the water in this temperature range was less than half of the water that might be considered available to Chinook salmon. The addition of data from months beyond August to October extends that initial finding. Chinook salmon use this narrow range of temperature throughout the year.

Relative to temperature, there was more individual and seasonal variability in the depths used. We propose a hypothesis for each source of variation. First, we suggest that the variation in depth use across individuals probably derives from thermoregulatory behaviors exhibited in response to changes in these months in the analysis did not change the overall conclusion that Chinook salmon used deeper habitats when the IHP indicated that surface habitats were restricted during May to September.

Annual cycles in SCCs within our study area spanned 3 orders of magnitude (range $=0.2$ to

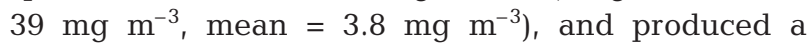
spatially variable cycle in accumulation rates over the 2000 to 2003 period (Fig. 9). When the coast-wide average $\mathrm{SCC}$ was $>4 \mathrm{mg} \mathrm{m}^{-3}$, Chinook salmon typically used waters shallower than about $150 \mathrm{~m}$ (Fig. 10). When average SCCs were $<4 \mathrm{mg} \mathrm{m}^{-3}$, the average depths used by the fish ranged from 0 to $250 \mathrm{~m}$. Chinook salmon only used depths that averaged $>150 \mathrm{~m}$ during the winter (December to February).

The depths used on a monthly basis varied depending on the combination of SST and SCCs that were encountered. During summer, when SSTs were within the 8 to $12^{\circ} \mathrm{C}$ range and SCC concentrations exceeded $4 \mathrm{mg} \mathrm{m}^{-3}$, Chinook salmon consistently used the shallowest habitats (Fig. 11). As SSTs warmed beyond $12^{\circ} \mathrm{C}$ in early autumn, depth use increased (Fig. 11). Finally, the deepest habitats were used during the period of lowest SCCs from December through February, and the use of shallower habitats resumed as SCCs increased during the spring months (Fig. 11).

\section{DISCUSSION}

From 2000 to 2003, the Chinook salmon tagged in this study used habitats in the coastal waters of Oregon and California that are described, as a rule of thumb,

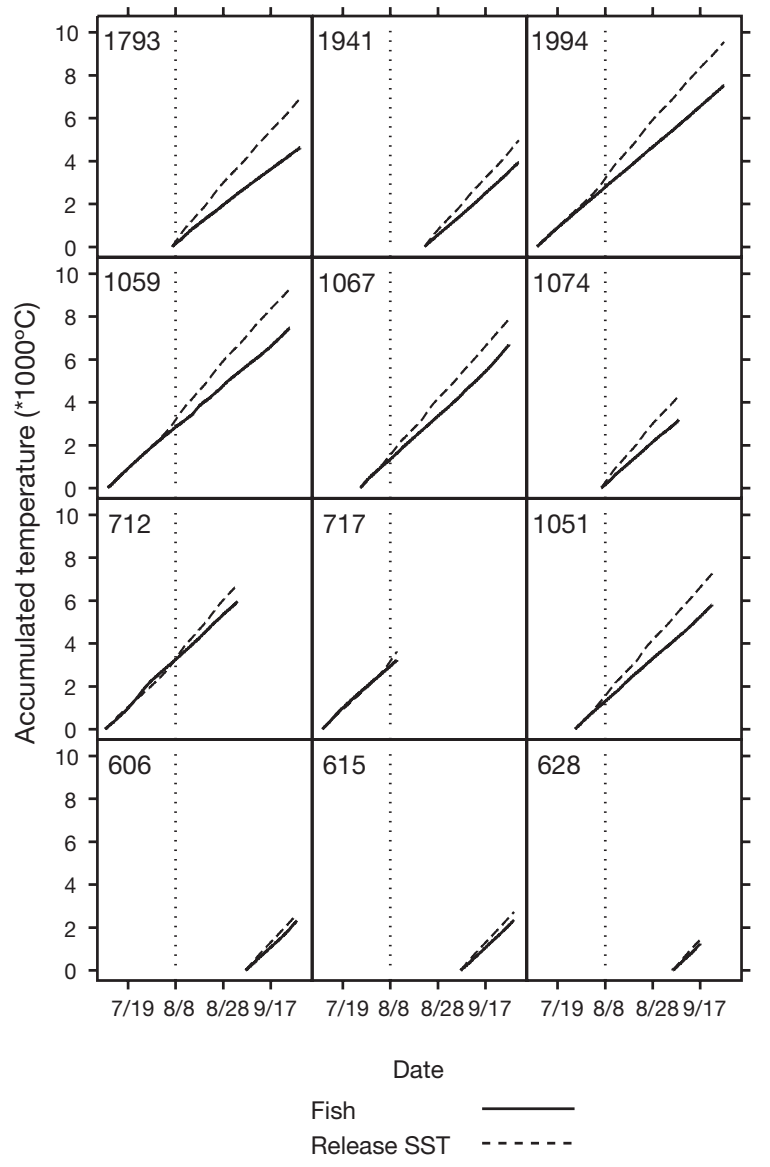

Fig. 6. Oncorhynchus tshawytscha. Temperature accumulations of all Chinook salmon released in 2003 and sea-surface temperatures (SST) at buoy nearest to each release location. Tag nos. shown at top left of each graph. Vertical dashed lines mark August 8; after this date, SSTs and temperature experienced by fish diverged (see 'Results') 


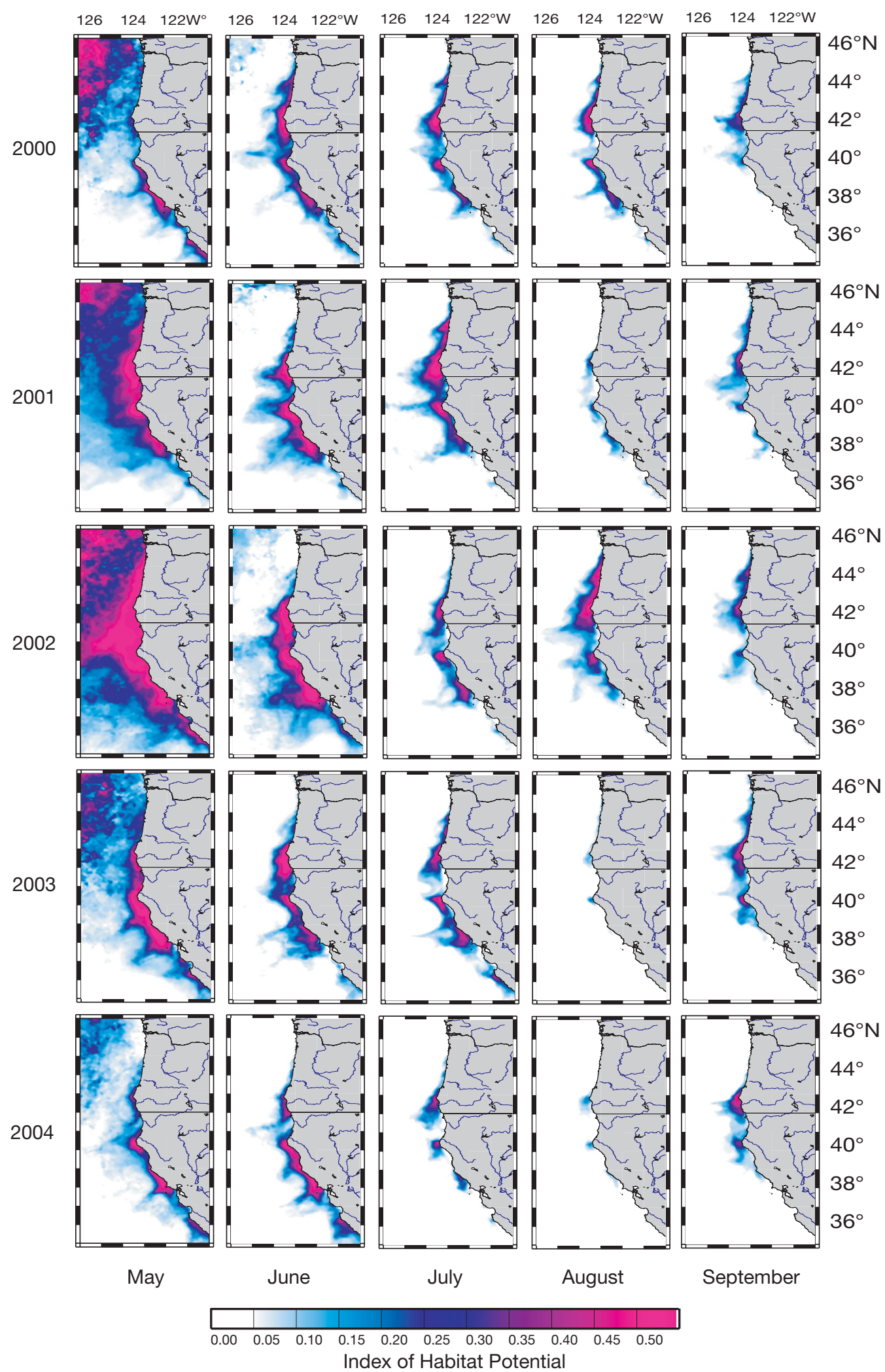

Fig. 7. Oncorhynchus tshawytscha. Availability of potential surface habitat in coastal ocean between 36 and $46^{\circ} \mathrm{N}$ from May to September of each year 


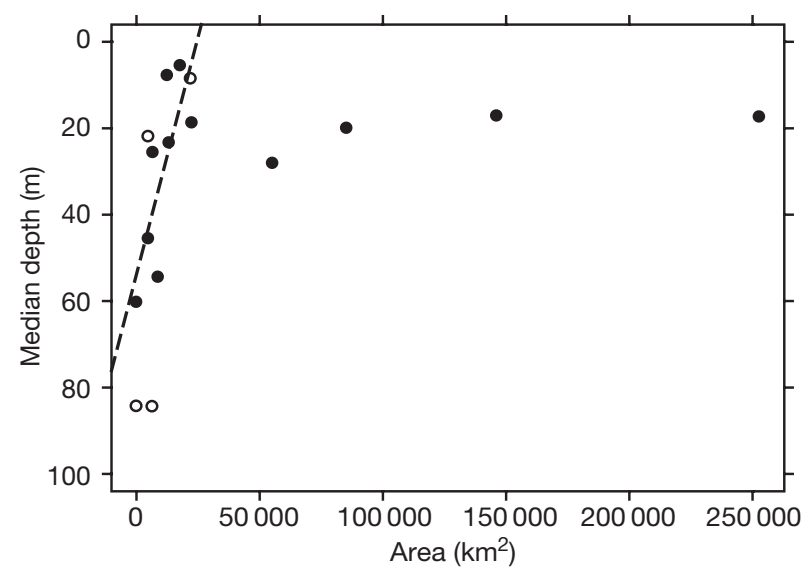

Fig. 8. Oncorhynchus tshawytscha. Median monthly depth use of fish and area of surface where index of habitat potential (IHP) was $>0.25$. Linear regression (dashed line) fitted only to data from 2000 to 2003 for IHP areas $<25000 \mathrm{~km}^{2}$; data from 2004 (open circles) were not used to estimate relationship

local thermal conditions. Second, the seasonal cycle in depth use may be driven by temperature-dependent bioenergetics, whereby a general decline in surface productivity during winter may insufficiently support the prey resources necessary to meet the energetic demands of Chinook salmon. These 2 hypotheses are based on the relative persistency of the temperatures experienced by the fish, and we explore each hypothesis in the following paragraphs.

Individual variation in depth use can be explained by thermoregulatory behaviors in response to variability in local thermal conditions. In river environments, thermoregulatory behaviors have been documented for Chinook salmon during seaward migrations by smolts (Sauter et al. 2001) and during spawning migrations by adults (Berman \& Quinn 1991). In the ocean, 3 lines of evidence support the hypothesis of behavioral thermoregulation: (1) all salmon used the same narrow window of water temperatures between 8 and $12^{\circ} \mathrm{C}$ throughout the year. (2) The synchronous use of deeper habitats by all 12 fish in August 2003 corresponded with increasing rates of SST accumulation in areas where they had been recently released, and the depths used by all the fish were similar to the vertical distributions of temperatures in the 8 to $12^{\circ} \mathrm{C}$ range in Monterey Bay. This suggests that the fish changed their vertical distribution and used, on average, cooler subsurface

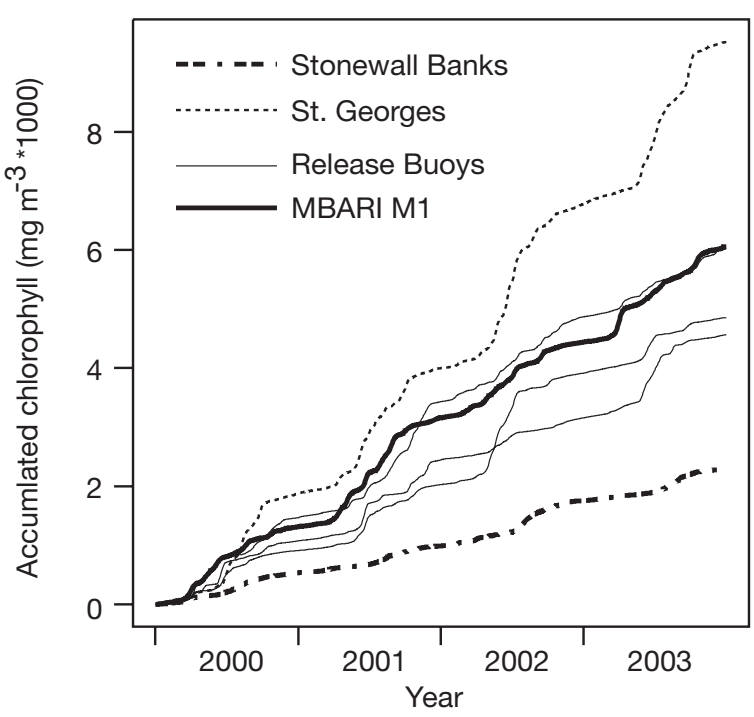

Fig. 9. Cumulative sums of daily surface chlorophyll a concentrations over $4 \mathrm{yr}$ near NOAA and MBARI moored buoys along coasts of Oregon and California

waters as coastal SSTs warmed. (3) Across all years for which the data extend into autumn, there was a divergence of the accumulated SSTs and the temperatures experienced by the fish. This divergence arises from the general increase in SSTs during autumn and a slight decrease in the rate of temperature accumulation by the fish that resulted from the use of deeper, relatively colder, water in the 8 to $12^{\circ} \mathrm{C}$ range. The exact timing of this divergence varied with respect to

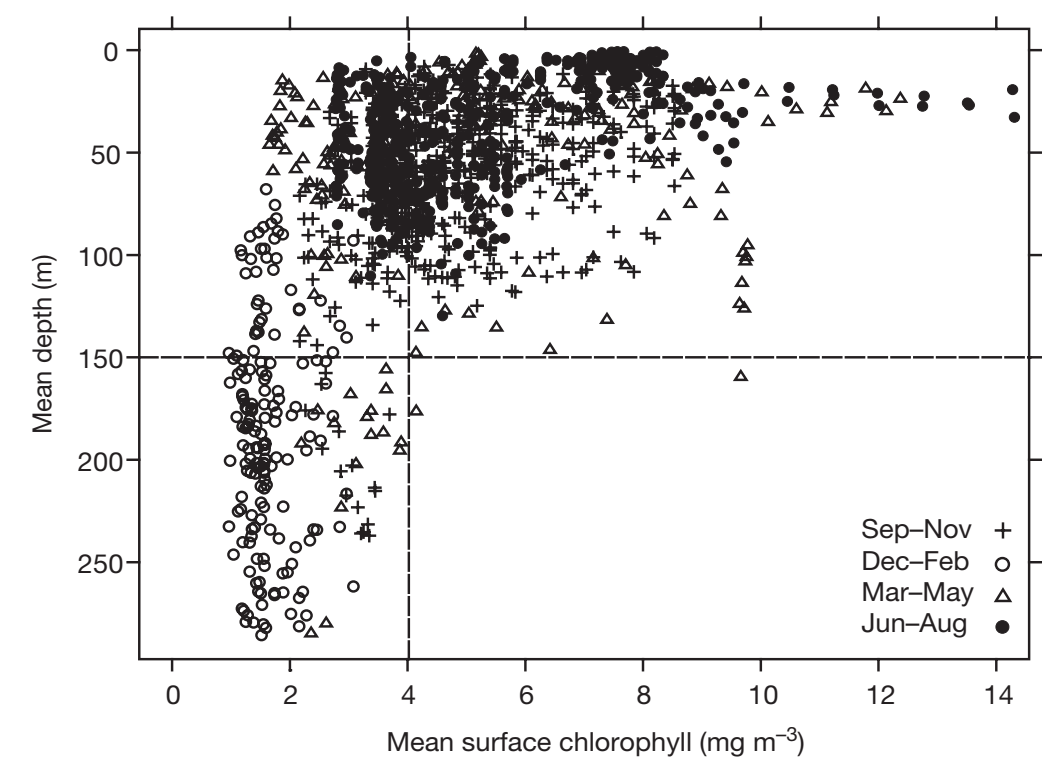

Fig. 10. Oncorhynchus tshawytscha. Daily mean fish depth versus coastwide, daily mean surface chlorophyll a concentration 


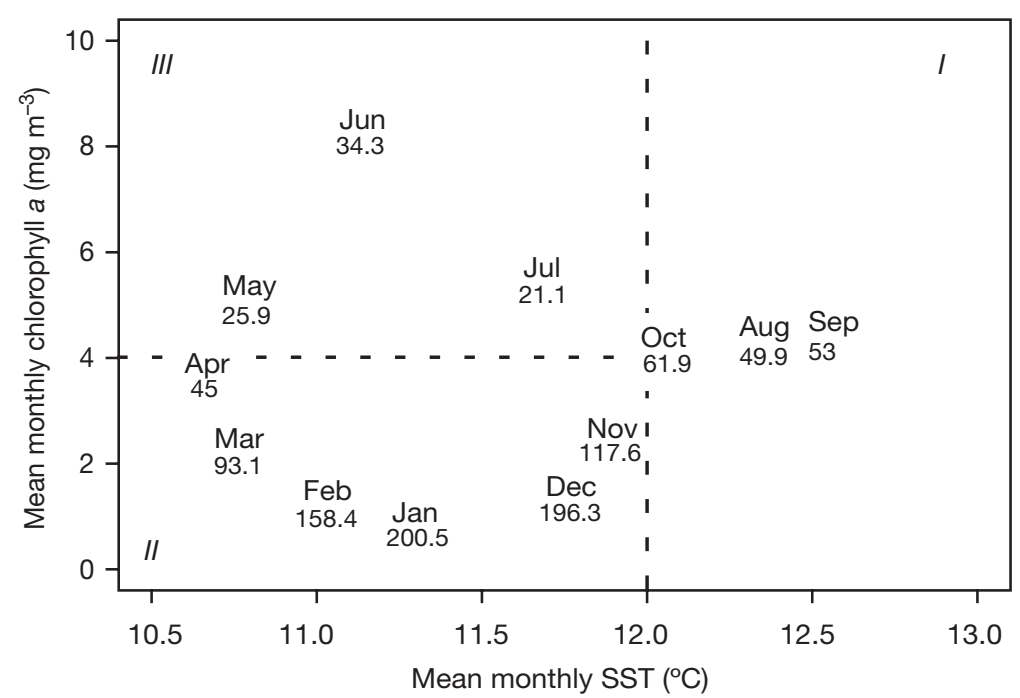

Fig. 11. Oncorhynchus tshawytscha. Monthly mean surface chlorophyll a concentrations, mean sea-surface temperatures, and mean monthly depth (m) use of fish (value below each month). I, II, and III: autumn period of intermediate-depth use, winter period of deep-habitat use and spring and summer period of shallow-habitat use, respectively

both year and position along the coast, but the divergence typically occurred from late August to early September, when SSTs warmed slightly. Other sources of variability in depth use across individuals undoubtedly arise from constraints imposed by bottom depths and the locations and movements of prey. These factors, however, are more likely to be the proximate sources of variation in depth.

The seasonal cycle in depth use may reflect a tradeoff between the energetic demands of Chinook salmon and the seasonal cycle in primary production. Assuming a relatively constant temperature experience, the total energetic demand for food will increase as an individual grows and matures. We assume that the narrow range of temperatures used qualifies as a sufficiently constant thermal experience to imply that, during winter, the energetic demands of Chinook salmon do not decrease. Demand might, in fact, increase if the fish continue to grow throughout the winter. However, the declining input of nutrient-rich water that coincides with weakened upwelling during autumn triggers a seasonal decline in primary productivity near the coast. The annual reduction in coastal productivity during winter may not sufficiently support the epipelagic prey resources (e.g. Hunt et al. 1999) necessary for Chinook salmon populations. The salmon used the deepest habitats during winter, when surface primary productivity was lowest, and as surface productivity increased during the spring, they returned to shallower habitats (see Fig. 11). The shallowest habitats were used when SCCs exceeded $4 \mathrm{mg} \mathrm{m}^{-3}$, but only when SSTs were $<12^{\circ} \mathrm{C}$. This cyclical pattern of depth use from shallower, predominantly epipelagic habitats during summer (e.g. Candy \& Quinn 1999, Hinke et al. 2005) to deeper, possibly benthic, habitats during winter is further supported by evidence from bottom-trawl fisheries off the coasts of Oregon and California. Erickson \& Pikitch (1994) reported that Chinook salmon were caught frequently in bottom trawls at depths between 100 and $482 \mathrm{~m}$ during the winter, but only rarely at depths exceeding $200 \mathrm{~m}$ during the summer. Presumably, the seasonal cycle of depth use simply reflects the location of a suitable combination of food availability and temperature.

The similar rates of temperature accumulation across individuals in the ocean are important for understanding the effect of oceanographic variability on Chinook salmon populations. The physiological functions of this fish, as for all poikilothermic animals, are strongly temperature-dependent, and therefore the accumulated thermal history of an individual can influence its development. For example, the cumulative temperature experience of Chinook salmon eggs can be used to predict the timing of hatching (e.g. Alderdice \& Velsen 1978). The predictive capacity of temperature accumulation during these earliest life-history stages arises largely from a shared thermal experience in the absence of confounding variation in their environment (eggs, for example, are dependent on internal energy stores). By extension, a similarity of temperature accumulation rates across individuals at similar life stages, particularly for individuals from the same local population or stock, should lead to similar growth and maturation rates. There is, however, notable variation in the developmental processes that salmon undergo during their residence in the ocean that contributes to the variation in, for example, the size and age at maturity and fecundity of individuals. This developmental variation cannot be explained by the similar rates of temperature accumulations across individuals. Rather, we suggest that changing ocean conditions influence the development of individuals (with consequent populationlevel responses) by changing food-web topology. Variation in environmental conditions in the California Current can alter food webs in subtle ways (e.g. Brodeur \& Pearcy 1992, Brodeur et al. 2003), and such changes may alter the type and quality of food, and the type and effectiveness of predators in the habitats used by Chinook salmon. 
The persistent pattern of temperature use observed here is also relevant to understanding the distribution of Chinook salmon at sea. The SSTs recorded by the moored buoys provided a reasonable approximation of the temperatures that were experienced by the fish during the summer, and the IHP provided a coast-wide assessment of where those conditions were likely to be met, particularly when these fish are targeted by commercial and recreational fisheries. Predictions based on the IHP appear consistent with an analysis by Botsford \& Lawrence (2002), who showed that catches of Chinook salmon were correlated most strongly with surface-based indices (SST, sea-surface height and upwelling) in spring and summer, and that the correlations varied spatially along the coasts of Oregon and California. The IHP showed spatial variation during summer, and the total area of potential surface habitat was related to the patterns of depth use by Chinook salmon.

An important limitation of our current IHP, however, is that it is entirely based on SSTs. It is reasonable to assume that an index of habitat availability could be improved in 2 main ways: (1) the inclusion of subsurface temperature data could provide better assessments of habitat availability. Subsurface habitats are used extensively by Chinook salmon throughout the year (Ogura \& Ishida 1995, Orsi \& Wertheimer 1995, Hinke et al. 2005), and exclusively during winter months. We have made a preliminary attempt to compare depth use by Chinook salmon with subsurface temperatures in Monterey Bay (Fig. 5). The close correspondence of depth use within the 8 to $12^{\circ} \mathrm{C}$ range provides support for further exploration of subsurface thermal structure as a means to better define ocean habitats for this fish. At present, however, the ability to assess accurately the availability of subsurface habitats is constrained by a paucity of subsurface temperature data on a scale that is suitable for mapping coastal habitats. The development of ocean circulation models and the increased use of archival tagging technologies and autonomous sampling devices may help to close this data gap and improve assessments of the subsurface habitats available for Chinook salmon. (2) Our results suggest that surface productivity plays a role in habitat selection (e.g. Fig. 11). The incorporation of surface productivity may further refine an IHP for coastal areas. At this point, however, we can not confirm that Chinook salmon used the habitats identified by the SST-based IHP. Therefore, we feel that implementing revisions to the IHP in the face of an unconfirmed assumption is beyond the scope of this manuscript.

In summary, our analysis of the data recorded by archival tags attached to 25 Chinook salmon during 4 yr (2000 to 2003) suggests persistent patterns of ther- mal habitat use that apply year-round. Depth use varied individually and seasonally, but all individuals appeared to respond in a similar ways to contemporary variation in ocean conditions, such that their temperature experiences remained within the narrow range of 8 to $12^{\circ} \mathrm{C}$. We argue that the individual variation in depth use can largely be explained by thermoregulatory behaviors and that seasonal variation in depth use is explained by seasonal variation in the extent of thermal habitats and the productivity within them. Our results provide support for hypotheses suggesting that changing ocean conditions can affect salmon populations, but we suggest that such effects may not result solely from temperature-dependent physiology. Rather, the interactions between variations in the extent of thermal habitats that are suitable for Chinook salmon and the food-web topology within these habitats seems likely to cause variation in the structure and abundance of their populations.

Acknowledgements. We gratefully acknowledge the many persons who provided fishing vessels, assisted in field work, and voluntarily returned tags over the past $5 \mathrm{yr}$. Suggestions by B. Wells, M. Snover, C. Bessey, P. Klimley and 2 anonymous referees improved earlier versions of this manuscript. SeaWiFS data provided by courtesy of Orbimage and NASA Goddard Space Flight Center DAAC; AVHRR SST data by courtesy of NOAA West Coast CoastWatch node, NOAA NWS (Monterey), and NOAA Satellite Active Archive; weather buoy SST data by courtesy of NOAA National Data Buoy Center; and M1 mooring data by courtesy of Monterey Bay Aquarium Research Institute.

\section{LITERATURE CITED}

Adkison MD, Peterman RM, Lapointe M, Gillis DM, Korman J (1996) Alternative models of climatic effects on sockeye salmon, Oncorhynchus nerka, productivity in Bristol Bay, Alaska, and the Fraser River, British Columbia. Fish Oceanogr 5:137-152

Alderdice DF, Velsen FPJ (1978) Relation between temperature and incubation time for eggs of chinook salmon Oncorhynchus tshawytscha. J Fish Res Board Can 35: 69-75

Beamish RJ (1993) Climate and exceptional fish production off the west coast of North America. Can J Fish Aquat Sci 50:2270-2291

Beamish RJ, Bouillon DR (1993) Pacific salmon production trends in relation to climate. Can Fish Aquat Sci 50: 1002-1016

Berman CH, Quinn TP (1991) Behavioral thermoregulation and homing by spring Chinook salmon, Oncorhynchus tshawytscha (Walbaum), in the Yakima River. J Fish Biol 39:301-312

Botsford LW, Lawrence CA (2002) Patterns of co-variability among California Current chinook salmon, coho salmon, Dungeness crab, and physical oceanographic conditions. Prog Oceanogr 53:283-305

Bradshaw CJA, Hindell MA, Michael KJ, Sumner MD (2002) The optimal spatial scale for the analysis of elephant seal 
foraging as determined by geo-location in relation to seasurface temperatures. ICES J Mar Sci 59:770-781

Brodeur RD, Pearcy WG (1992) Effects of environmental variability on trophic interactions and food web structure in a pelagic upwelling system. Mar Ecol Prog Ser 84:101-119

Brodeur RD, Pearcy WG, Ralston S (2003) Abundance and distribution patterns of nekton and micronekton in the northern California Current transition zone. J Oceanogr 59:515-535

Candy JR, Quinn TP (1999) Behavior of adult chinook salmon (Oncorhynchus tshawytscha) in British Columbia coastal waters determined from ultrasonic telemetry. Can J Zool 77:1161-1169

Clark WG, Hare SR, Parma AM, Sullivan PJ, Trumble RJ (1999) Decadal changes in growth and recruitment of Pacific Halibut (Hippoglossus stenolepis). Can J Fish Aquat Sci 56:242-252

Collins CA, Pennington JT, Castro CG, Rago TA, Chavez FP (2003) The California Current system off Monterey, California: physical and biological coupling. Deep-Sea Res II 50:2389-2404

Erickson DL, Pikitch EK (1994) Incidental catch of Chinook salmon in commercial bottom trawls of the US west coast. North Am J Fish Manag 14:550-563

Friedland KD, Walker RV, Davis ND, Myers KW, Boehlert GW, Urawa S, Ueno Y (2001) Open-ocean orientation and return migration routes of chum salmon based on temperature data from data storage tags. Mar Ecol Prog Ser 216: $235-252$

Gargett AE, Li M, Brown R (2001) Testing mechanistic explanations of observed correlations between environmental factors and marine fisheries. Can J Fish Aquat Sci 58: 208-219

Hickey BM (1998) Coastal oceanography of western North America from the tip of Baja California to Vancouver Island. In: Robinson AR, Brink KH (ed) The sea. Vol 11. John Wiley \& Sons, New York, p 345-393

Hinch SG, Healey MC, Diewert RE, Thomson KA, Hourston R, Henderson MA, Juanes F (1995) Potential effects of climate change on marine growth and survival of Fraser River sockeye salmon. Can J Fish Aquat Sci 52:2651-2659

Hinke JT, Watters GM, Boehlert GW, Zedonis P (2005) Ocean habitat use in autumn by Chinook salmon in coastal waters of Oregon and California. Mar Ecol Prog Ser 285: 181-192

Hobday AJ, Boehlert GW (2001) The role of coastal ocean variation in spatial and temporal patterns in survival and size of coho salmon (Oncorhynchus kisutch). Can J Fish Aquat Sci 58:2021-2036

Hunt SL, Mulligan TJ, Komori K (1999) Oceanic feeding habits of Chinook salmon, Oncorhynchus tshawytscha, off northern California. Fish Bull (US) 97:717-721

Insightful Corporation (2001) S-PLUS 6 for Windows guide to statistics, Vol 1. Insightful Corporation, Seattle, WA

Itoh T, Tsuji S, Nitta A (2003) Swimming depth, ambient water

Editorial responsibility: Otto Kinne (Editor-in-Chief), Oldendorf/Luhe, Germany temperature preference, and feeding frequency of young Pacific bluefin tuna (Thunnus orientalis) determined with archival tags. Fish Bull (US) 101:535-544

Lynn RJ, Bograd SJ, Chereskin TK, Huyer A (2003) Seasonal renewal of the California Current: the spring transition of California. J Geophys Res C 108:3279, doi:10.1029/ 2003JC001787

Mendelssohn R, Schwing FB, Bograd SJ (2003) Spatial structure of subsurface temperature variability in the California Current, 1950-1993. J Geophys Res C 108:3093 doi: 10.1029/2002JC001568

Mueter FJ, Ware DM, Peterman RM (2002) Spatial correlation patterns in coastal environmental variables and survival rates of salmon in the north-east Pacific Ocean. Fish Oceanogr 11:205-218

Ogura M, Ishida Y (1995) Homing behavior and vertical movements of four species of Pacific salmon (Oncorhynchus spp.) in the central Bering Sea. Can J Fish Aquat Sci 52:532-540

Orsi JA, Wertheimer AC (1995) Marine vertical distribution of juvenile Chinook and coho salmon in southeastern Alaska. Trans Am Fish Soc 124:159-169

Pearcy WG (1992) Ocean ecology of north Pacific salmonids. University of Washington Press, Seattle

Pearcy WG, Schoener A (1987) Changes in marine biota coincident with the 1982-1983 El Niño in the northeastern subarctic Pacific ocean. J Geophys Res C 92:14417-14428

Peterman RM, Pyper BJ, Lapointe MF, Adkison MD, Walters CJ (1998) Patterns of covariation in survival rates of British Columbian and Alaskan sockeye salmon (Oncorhynchus nerka) stocks. Can J Fish Aquat Sci 55:2503-2517

Rodríguez-Sánchez R, Lluch-Belda D, Villalobos H, OrtegaGarcía S (2002) Dynamic geography of small pelagic fish populations in the California Current System on the regime time scale (1931-1997). Can J Fish Aquat Sci 59: 1980-1988

Roy D, Haffner GD, Brandt SB (2004) Estimating fish production potentials using a temporally explicit model. Ecol Model 173:241-257

Sauter ST, Crawshaw LI, Maule AG (2001) Behavioral thermoregulation by juvenile spring and fall chinook salmon, Oncorhynchus tshawytscha, during smoltification. Environ Biol Fish 61:295-304

Sims DW, Southall EJ, Richardson AJ, Reid PC, Metcalfe JD (2003) Seasonal movements and behaviour of basking sharks from archival tagging: no evidence of winter hibernation. Mar Ecol Prog Ser 248:187-196

Snover ML, Watters GM, Mangel M (2005) Interacting effects of behavior and oceanography on growth in salmonids with examples from coho salmon (Oncorhynchus kisutch). Can J Fish Aquat Sci 62:1219-1230

Walker RV, Myers KW, Davis ND, Aydin KY and 5 others (2000) Diurnal variation in thermal environment experienced by salmonids in the North Pacific as indicated by data storage tags. Fish Oceanogr 9:171-186

Submitted: January 5, 2005; Accepted: June 24, 2005

Proofs received from author(s): October 28, 2005 